\title{
RUÍNAS E RESÍDUOS: DRUMMOND ENTRE A POESIA E A ANTIPOESIA
}

\author{
Maura Voltarelli
}

Submetido em 23 de maio de 2018.

Aceito para publicação em 31 de outubro de 2018.

Cadernos do IL, Porto Alegre, n. ${ }^{\circ}$ 57, novembro de 2018. p. 166- 179

\section{POLÍTICA DE DIREITO AUTORAL}

Autores que publicam nesta revista concordam com os seguintes termos:

(a) Os autores mantêm os direitos autorais e concedem à revista o direito de primeira publicação, com o trabalho simultaneamente licenciado sob a Creative Commons Attribution License, permitindo o compartilhamento do trabalho com reconhecimento da autoria do trabalho e publicação inicial nesta revista.

(b) Os autores têm autorização para assumir contratos adicionais separadamente, para distribuição não exclusiva da versão do trabalho publicada nesta revista (ex.: publicar em repositório institucional ou como capítulo de livro), com reconhecimento de autoria e publicação inicial nesta revista.

(c) Os autores têm permissão e são estimulados a publicar e distribuir seu trabalho online (ex.: em repositórios institucionais ou na sua página pessoal) a qualquer ponto antes ou durante o processo editorial, já que isso pode gerar alterações produtivas, bem como aumentar o impacto e a citação do trabalho publicado.

(d) Os autores estão conscientes de que a revista não se responsabiliza pela solicitação ou pelo pagamento de direitos autorais referentes às imagens incorporadas ao artigo. A obtenção de autorização para a publicação de imagens, de autoria do próprio autor do artigo ou de terceiros, é de responsabilidade do autor. Por esta razão, para todos os artigos que contenham imagens, o autor deve ter uma autorização do uso da imagem, sem qualquer ônus financeiro para os Cadernos do IL.

\section{POLÍTICA DE ACESSO LIVRE}

Esta revista oferece acesso livre imediato ao seu conteúdo, seguindo o princípio de que disponibilizar gratuitamente o conhecimento científico ao público proporciona sua democratização. 


\title{
RUÍNAS E RESÍDUOS: DRUMMOND ENTRE A POESIA E A ANTIPOESIA
}

\section{RUINS AND REFUSE: DRUMMOND BETWEEN POETRY AND ANTI-POETRY}

\author{
Maura Voltarelli*
}

\begin{abstract}
RESUMO: $O$ artigo tem como objetivo aproximar a reflexão sobre a antipoesia, desenvolvida pelo poeta francês Francis Ponge, da tradição moderna e contemporânea da poesia brasileira, pensando, particularmente, a questão da contrapoesia ou da antipoesia na obra do poeta Carlos Drummond de Andrade. O artigo se concentra no livro Claro Enigma, publicado em 1951, no qual parece se realizar justamente uma intensificação da questão poética pelo aspecto de autocrítica da poesia que atravessa a obra, reforçado, de certa forma, pelo seu tom de desencanto.
\end{abstract}

PALAVRAS-CHAVE: antipoesia; Carlos Drummond de Andrade; Claro Enigma; poesia brasileira.

ABSTRACT: The article aims to bring the debate on the anti-poetry, developed by the French poet Francis Ponge, to the modern and contemporary tradition of Brazilian poetry, thinking, particularly, the issue of counterpoetry or anti-poetry in the work of the poet Carlos Drummond de Andrade. The article focuses on the book Claro Enigma, published in 1951, in an intensification of poetic question seems to be performed by the aspect of self-criticism of poetry that crosses the work, reinforced, in a way, by its disenchanted tone.

KEYWORDS: antipoetry; Carlos Drummond de Andrade; Claro Enigma, Brazilian poetry.

Sou eu, o poeta precário do poema "O Mito", de A Rosa do Povo

\section{Introdução}

\begin{abstract}
Não poderíamos imaginar uma espécie de escritos (novos) que, situando-se aproximadamente entre os dois gêneros (definição e descrição), tomariam emprestados do primeiro sua infalibilidade, sua indubitabilidade, sua brevidade também, do segundo seu respeito pelo aspecto sensorial das coisas... (PONGE, 1961, p. 516-517, tradução própria).
\end{abstract}

Neste fragmento do texto "My creative method", do poeta francês Francis Ponge, ele desenvolve o que seria uma espécie de lugar intervalar por onde deveriam passar os novos escritos poéticos. Tais escritos, segundo ele, deveriam opor-se a um tipo de poesia mais próxima do abstrato da filosofia do que do sensível das coisas e da materialidade das palavras. Ponge viria a representar, neste sentido, uma tradição objetivista da poesia francesa, que se opõe ao chamado "lirismo", e é marcada por um forte aspecto crítico, pela negatividade e pela atitude antipoética de se colocar contra uma determinada poesia que era feita até então.

No livro Le Partis pris de choses, publicado em 1942, logo no título Ponge

* Doutoranda em Teoria e História Literária no Instituto de Estudos da Linguagem (IEL), da Universidade Estadual de Campinas (UNICAMP), Mestre em Teoria e História Literária pela mesma universidade, bolsista da Fundação de Amparo à Pesquisa do Estado de São Paulo (FAPESP), ma_voltarelli@yahoo.com.br 
expõe a tomada de partido pelas coisas, e não pelas ideias, pensando uma poética que passasse também por uma estratégia de limpeza em prol das coisas insignificantes ${ }^{51}$. As questões centrais da antipoesia pensada por Ponge seriam a dessubjetivação, que passa por uma problematização da figura do eu; o inacabamento, que passa pela crítica de uma espécie de formalismo poético e relativiza elementos básicos da poesia, como o verso, e a atitude contrária a uma poesia metafórica, que passa pela recusa da figuração lírica. O projeto de Ponge abarcaria um "contra a poesia inteira", gesto que parece intensificar os conflitos no campo poético.

Em uma tentativa de aproximar a reflexão sobre a antipoesia da tradição moderna e contemporânea da poesia brasileira, este ensaio buscará pensar a questão da contrapoesia ou da antipoesia na obra do poeta Carlos Drummond de Andrade, concentrando-se no livro Claro Enigma, publicado em 1951, no qual parece se realizar justamente uma intensificação da questão poética pelo aspecto de autocrítica da poesia que atravessa a obra, reforçado, de certa forma, pelo seu tom de desencanto.

\title{
2. Drummond e a antipoesia
}

No caminho poético de Carlos Drummond de Andrade, alguns dos poemas centrais em sua obra permitem traçar uma espécie de "movimento contrapoético", sinalizando gestos de questionamento menos da poesia em si e mais de certo tipo de poesia a que o poeta, em proporções e intensidades que variam nos seus diferentes livros, contrapõe um outro modelo de escrita e de pensamento sobre o mundo.

Desde o início já próximo do movimento modernista e de seus nomes principais, é ao amigo Mário de Andrade que ele dedica seu primeiro livro de poemas, Alguma Poesia, publicado em 1930, no qual Drummond constrói uma poesia que, seja pela forma ou pela temática, questiona o lirismo e o formalismo de movimentos poéticos como o Simbolismo e o Parnasianismo.

Um exemplo significativo em sua obra inicial, desse gesto poético de se colocar "contra" toda uma poesia que era feita até então, é o poema fundamental e que se prolongará em outros ecos e ressonâncias por toda sua obra: "No meio do caminho",52.

\author{
No meio do caminho tinha uma pedra \\ tinha uma pedra no meio do caminho \\ tinha uma pedra \\ no meio do caminho tinha uma pedra. [...] \\ (DRUMMOND, 1973, p. 61)
}

Tem-se um poema com poucas palavras, de forma repetitiva, que insiste em dizer "tinha uma pedra no meio do caminho", empregando, contra as regras e padrões formais de então, o verbo "ter" no lugar do verbo "haver". Como elemento poético, surge a pedra diante da qual o poeta para, para jamais se esquecer desse acontecimento na vida de suas "retinas tão fatigadas". "No meio do caminho" parece representar, na obra de Drummond, um gesto de contraposição flagrante e, ao mesmo tempo,

51 No seu texto "Le savon", publicado em 1967, Ponge fala em "toilette intellectuelle" para se referir ao processo de limpeza da linguagem, cujo objetivo seria retirar seus excessos, deixando-a mais objetivista e próxima das coisas, o que guarda certa proximidade com o que disse Valéry (1991) no texto "Poesia e Pensamento Abstrato", ao falar da "limpeza da situação verbal".

52 Todos os poemas de Drummond citados neste trabalho foram retirados de: ANDRADE, Carlos Drummond de. Poesia completa e prosa organizada pelo autor. Nota editoral: Afrânio Coutinho. Introd. Emanuel de Moraes. Rio de Janeiro: Companhia José Aguilar Editora, 1973. 
profundamente reflexivo. A pedra incomoda, perturba, interrompe a marcha do poeta, faz com que ele se detenha e pense sobre aquela presença inoportuna porém tão insistente.

Insistente também é a dúvida que atravessa o poema "José", publicado no livro seguinte ao Alguma Poesia e que leva o mesmo nome, cuja primeira edição é de 1942. Em "José", diante de um sujeito marcado por sucessivas insuficiências e ausências, desenha-se uma perturbação da existência, dúvidas, desejos, excessos, sonhos vãos; não há sequer destino, a julgar pela pergunta do poema: "José, para onde?". O poema traz um sujeito desamparado diante de um mundo que lhe é indiferente, que lhe impede a existência plena e o arremessa no caos. Nessa indagação existencial que o poema propõe, há a reflexão sobre o sujeito moderno - os tantos Josés espalhados por esse "mundo caduco" para o qual trabalhamos sem alegria, como diz o poema "Elegia 1938", de Sentimento do Mundo - e tal reflexão parece comunicar-se também a uma reflexão sobre o próprio fazer poético na modernidade: qual seria então o lugar da poesia? O poema diz: "sua doce palavra,/seu instante de febre,/sua gula e jejum,/sua biblioteca,/" e termina por sugerir que tudo isso não serve para nada.

"José" é um poema feito de negatividades, cuja negação profunda questiona, reverbera em inúmeros "se", para talvez apresentar uma poesia que, diante do desamparo do sujeito moderno, parece buscar ser também ela uma forma de desamparo, questionadora de sua própria natureza, não podendo ser mais a mesma, reflexo de um mundo novo, de um novo homem, uma nova poesia.

No mesmo livro, o poema "O Lutador" parece tematizar certo processo antipoético em que "lutar com palavras/é a luta mais vã", em um inútil duelo que jamais se resolve. Aqui, a poesia que se escreve contra uma poesia já caduca é a poesia que se faz com palavras, para lembrarmos Mallarmé ${ }^{53}$, e o poeta é este que luta com as palavras ou, em alguns casos, aquele que luta nas palavras. Mesmo sabendo que tal luta está condenada a jamais se resolver (a apenas envolver indefinidamente), ele a persegue, talvez justamente por essa impossibilidade.

E como num bordado, onde um movimento se comunica e leva a outro, dando, aos poucos, uma forma à figura bordada, cada um tendo, no entanto, o seu propósito e a sua intensidade, o poema "Procura da Poesia", do livro A Rosa do Povo, de 1945, marca de forma expressiva a ideia de uma poesia feita de palavras, centrada na linguagem, ao dizer, depois de uma série de negativas e interdições: "penetra surdamente no reino das palavras./Lá estão os poemas que esperam ser escritos." Ainda que Drummond, de certa forma, faça versos sobre acontecimentos, cante a sua cidade, recomponha sua sepultada infância ${ }^{54}$, o poema estabelece um ponto de partida - o reino das palavras - para que a experiência poética extrapole o "eu" e possa ir na direção do outro por meio do trabalho com e nas palavras. A palavra surge, então, como o lugar onde se deve procurar a poesia, lugar que certamente não poderia ser fácil de alcançar: "as palavras [...] rolam num rio difícil e se transformam em desprezo." (DRUMMOND, 1973, p. 139).

Na poesia de Drummond, a reflexão poética que se confronta com as palavras também se desdobra em uma ideia de resistência dessa poesia feita de palavras (pedregosa, indizível e fugidia), que sobrevive como um "apesar de". Não é outra a

53 Em "Poesia e Pensamento Abstrato", Valéry (1991) escreve: "O grande pintor Degas muitas vezes me contou essa frase de Mallarmé, tão justa e tão simples. Degas às vezes fazia versos, e deixou alguns deliciosos. Mas constantemente encontrava grandes dificuldades nesse trabalho acessório de sua pintura. Um dia disse a Mallarmé: "Sua profissão é infernal. Não consigo fazer o que quero e, no entanto, estou cheio de ideias..." E Mallarmé lhe respondeu: “Absolutamente não é com ideias, meu caro Degas, que se fazem os versos. É com palavras" (VALÉRY, 1991, p. 207-208).

54 Foram usadas nesse trecho imagens do próprio poema "Procura da poesia". 
imagem do poema tão conhecido de Drummond, "A Flor e a Náusea", um poema marcado pela dificuldade da época, indicando os traços de uma poética ainda bastante influenciada pelos acontecimentos, pelos signos de um mundo capitalista, "melancolias, mercadorias espreitam-me", que, em meio a uma negatividade entediante, encena o improvável nascimento de uma flor na rua. "É feia. Mas é uma flor. Furou o asfalto, o tédio, o nojo e o ódio." (DRUMMOND, 1973, p. 141). Metáfora drummondiana para a própria poesia, a flor, capaz de furar o asfalto, cujo lugar não é mais o campo, ou o jardim, e sim a rua, um tanto apagada e cujas pétalas tampouco se abrem, talvez seja, antes de tudo, uma metáfora para a antipoesia em sua "forma insegura", que já protagonizou o movimento moderno de "perder a sua auréola" 55 e assumiu para si a perigosa tarefa de sobreviver nesse lugar de passagem das coisas e dos homens. É como se, aqui, fossem recusadas todas as demais flores em nome dessa "forma improvável", a feia flor do asfalto.

No artigo "Carlos Drummond de Andrade: um ex-poeta, um poeta perturbado, um poeta precário", Alberto Pucheu (2014) recorda um verso de Drummond do poema "Brinde ao Juízo Final", de Sentimento do Mundo, que diz: "Em vão assassinaram a poesia nos livros", para em seguida problematizar a forma de resistência da poesia, o seu lugar em um tempo antipoético.

\begin{abstract}
Assassinada, a poesia é ainda possível, é ainda passível de alguma resistência? Haverá lugar para a poesia? Conseguirá a poesia, se é que ela morreu, de alguma maneira ressuscitar? [...] Qual o lirismo compatível com um tempo deteriorado e completamente antilírico? Que tipo de poesia insiste em uma época antilírica? (PUCHEU, 2014, p. 49).
\end{abstract}

As possíveis respostas a essas perguntas deixadas por Alberto Pucheu em um texto cuja reflexão parte justamente de $A$ Rosa do Povo, o livro de Drummond onde a pobreza de sua época se faz presente de forma bastante expressiva, talvez passem justamente pelo caminho antipoético, por uma incorporação do antilírico na própria lírica como uma possível forma de resistir nesse "tempo obscuro que silencia o poeta".

Pucheu (2014) aponta como caminho encontrado por Drummond a tentativa de “escrever tortuosamente, apenas um 'murmúrio' de 'palavras indiretas', sem centro ou sem base [...] Entre o silêncio e a fala, entre o não sentido e o sentido, o murmúrio, enquanto tom da poesia" (PUCHEU, 2014, p. 49). A poesia de Drummond, em vários momentos apontados por Pucheu, se mostra precária, insuficiente, espécie de reflexo pelo avesso de sua própria época, outro modo de dizer a sua negatividade. Mas o movimento essencial em Drummond, lembrado por Pucheu (2014), é aquele em que

$55-$ Eia! quê! tu aqui, meu caro? Tu, num lugar reles! tu, o bebedor de quintas-essências! tu, o saboreador da ambrósia! $\mathrm{Na}$ verdade, há nisto qualquer coisa que me surpreende. - Meu caro, conheces o meu pavor dos cavalos e das viaturas. Há pouco, ao atravessar o boulevard a toda a pressa, e ao saltar na lama através desse caos movimentado onde a morte avança a galope de todos os lados ao mesmo tempo, a minha auréola, num movimento brusco, caiu-me da cabeça no lodo do macadame. Não tive coragem para a apanhar. Julguei menos desagradável perder as minhas insígnias do que partir os ossos. E depois, disse comigo mesmo, há males que vêm por bem. Agora posso passear incógnito, fazer más acções, e entregar-me à crápula, como os simples mortais. E eis-me aqui, semelhante a ti, como vês! - Devias ao menos mandar anunciar essa auréola, ou fazê-la reclamar pelo comissário. - Por coisa alguma! Acho-me bem aqui. Só tu me reconheceste. Para mais, a dignidade aborrece-me. E também penso com satisfação que algum poetastro a vai apanhar e cobrir-se com ela impudentemente. Fazer alguém feliz, que alegria! e sobretudo um feliz que me fará rir! Ora pensa em X ou em Z! como será divertido! (BAUDELAIRE, 1991, p. 131-132). 
"ainda que precária e inacessível, a síntese de seu tempo, embora obscura, é buscada; nessa busca inglória, o único resultado é flagrar a perda de um objeto inacessível que se apresenta como o motor do poema" (PUCHEU, 2014, p. 50).

$\mathrm{Na}$ tentativa de dizer uma falta, na poesia de Drummond "as imagens se fazem, antes, como contraimagens, ou seja, existem antes para ocultar do que para revelar, existem antes para mostrar a falta do que para recobri-la" (PUCHEU, 2014, p. 50). Nesse sentido, parece possível dizer que os versos murmurantes de Drummond apresentam-se aos leitores de seu tempo sombrio como formadores de uma contrapoesia, ao mesmo tempo próxima e (cada vez mais) distante, aborrecida de sua época. "Mas, confundindo-se com a morte, o poema do tempo sombrio se sabe também o lugar parcial do morto, de um morto-vivo que, moribundo, ainda pode murmurar" (PUCHEU, 2014, p. 50).

Pequena imagem dessa sobrevivência do poema nos tempos sombrios, em que estão tematizados os restos e ruínas a partir dos quais se erguerá o verso drummondiano, também pode ser lida no poema "Resíduo" e em sua performance de uma nova repetição que diz: "de tudo ficou um pouco". Também podemos ver aqui, talvez, uma outra imagem para todas as depurações e "limpezas verbais" às quais deveria ser submetida a linguagem poética, de que nos falava Ponge.

Ao pensar esse poema de Drummond em diálogo com as discussões que estão em Valéry e, de forma ainda mais acentuada, em Ponge, uma vez feitas todas as limpezas verbais, a poesia ainda sai guardando algo, mesmo (e, talvez, propositalmente, pensando em Ponge) sendo esse algo que resta uma coisa tão insignificante quanto um botão, ou tão suja quanto um rato. Ao insistir no pequeno, no resíduo, na ruína, na flor ainda que feia, a poética drummondiana termina por transformá-los em uma espécie de relíquia, testemunhos de presenças fugidias, novas formas (poéticas) de sobreviver.

\section{A recusa da poesia em Claro Enigma}

Dos múltiplos momentos em que podemos ver desdobrada, de alguma forma, a questão da antipoesia na obra de Drummond, escolhemos analisar mais detidamente aquele do livro Claro Enigma (1951), que reúne poemas escritos entre 1948 e 1951, período que coincide com os anos do pós-guerra. O livro, que representaria uma "guinada classicizante operada na lírica de Drummond", para lembrar o que diz Vagner Camilo (1999) em Da Rosa do Povo à Rosa das Trevas, também é apontado por ele como "objeto de polarização da crítica, não raro tendendo a uma apreciação pouco valorativa, quando confrontada com a poesia social de A Rosa do Povo (1945) ou mesmo com a poesia objetual de Lição de Coisas (1961)" (CAMILO, 1999, p. 7). Sobre essa apreciação pouco valorativa da crítica em relação ao livro, Vagner Camilo ainda diz:

muitas das ressalvas feitas pelos intérpretes parecem decorrer seja da desconsideração para com as articulações mais íntimas e sempre dialéticas que unem o pessimismo e o formalismo de Claro Enigma a certas especificidades do contexto político e estético dos anos 40-50; seja da incompreensão frente à reapropriação drummondiana do legado "clássico", que nada tem de regressiva ou restauradora, como se costuma supor. (CAMILO, 1999, p. 8, grifos do autor)

Camilo (1999) propõe que o neoclassicismo e o formalismo de Claro Enigma teriam relação com um momento marcado pela crescente especialização do trabalho 
artístico. Já a frustração do projeto lírico-participante dos anos 40 e o pessimismo social dominante na obra são vistos por ele como decorrência do radicalismo ideológico do partido comunista no pós-guerra, que levaria à imposição do realismo socialista como padrão artístico a ser seguido à risca.

Para além dessas dimensões históricas e políticas, há outra questão que parece atravessar esse livro de Drummond: o questionamento do próprio fazer poético. Interessante pensar que justamente no livro onde Drummond faz uso de formas fixas, como soneto, versos rimados e metrificados, dentre outras formas clássicas, como os tercetos decassílabos de "A Máquina do Mundo", o que naturalmente poderia indicar uma afirmação da poesia pelo uso de suas formas mais tradicionais, é onde o próprio fazer poético se deixará ver mais frágil, "mais irritado", como sugere o título do poema "Oficina Irritada", questionado e contaminado de um desencanto fundo, de um pessimismo largo, a recortar o livro do começo ao fim.

Desde a epígrafe, uma frase de Valéry que diz: "os acontecimentos me aborrecem", Claro Enigma já se coloca como espécie de marco divisório na obra de Drummond, um daqueles instantes de pausa para o pensamento, quando uma obra, até então bastante participante e ligada aos acontecimentos de sua época, agora reclama de certo aborrecimento a partir do qual ela parece iniciar um processo de revisitação de si mesma para preparar seus futuros caminhos.

Igualmente importante, além da epígrafe, é a dedicatória do livro - a Américo Facó - poeta e jornalista cearense sobre quem Drummond escreveu na crônica "Poesia Nobre," reunida em Passeios na Ilha, destacando, entre outras coisas, a lição deixada pelo poeta que deve, como escreve Drummond (1973), "impressionar pelo que encerra de luminosa humildade; o poeta não é o portador do fogo sagrado, mas o precavido possuidor de uma lanterna de bolso, que abre caminho entre as trevas do dicionário" (ANDRADE, 1973, p. 861).

O que torna Claro Enigma um livro particularmente interessante na obra de Drummond e ainda mais sugestivo no que diz respeito à questão contrapoética, ou da antipoesia, parece estar no fato de que quando comparamos ou fazemos o exercício de ver juntos dois livros considerados tão opostos como A Rosa do Povo e Claro Enigma, parece-nos ser possível de um ao outro entender o processo de intensificação da questão contrapoética na obra de Drummond.

Em A Rosa do Povo, como bem aponta Pucheu em texto aqui já referido, há a percepção pelo poeta, manifesta nos poemas do livro, de uma precariedade da sua época que invade, contamina e se faz a matéria mesma dos seus poemas, estes últimos revelando-se eles próprios precários, mortos-vivos, imersos no sem sentido que é o sem sentido do próprio tempo. Mas, como se algo em A Rosa do Povo ainda fosse insuficiente, como se o poema lá ainda estivesse "claro demais", os acontecimentos "presentes demais", o poeta de Claro Enigma decide, por fim, logo na epígrafe, anunciar seu aborrecimento diante deles, para, apenas de forma aparente, expulsá-los do poema; decide, logo no título, instaurar o claro enigma, essencialmente obscuro, tensivo, e para isso faz poemas difíceis, em forma fixa, imersos de forma mais acentuada no "sem sentido", de modo que, em Claro Enigma, mais que em A Rosa do Povo, "a tentativa de decifração acaba por encontrar o próprio indecifrável" (PUCHEU, 2014, p. 50).

Muito parece estar dito na reflexão de Pucheu reproduzida a seguir quando pensamos na tensão que se coloca em Claro Enigma e a partir da qual o livro se faz:

Nessa tensão, nessa reversibilidade entre o poético e o impoético, entre o lírico e o antilírico, entre o canto e o não canto, entre o comunicável e o incomunicável, entre o descritível e o indescritível, nesse fracasso constante 
em encontrar o objeto - perdido - que busca, ele se coloca. Para isso, ele insiste, senão no sentido, impossível, de seu tempo, no desejo de palavras que digam o sem sentido de seu tempo, de palavras que, além disso, desfeitas de seu sentido, revoltam-se e, em sua incomunicabilidade, "irritadas", há muito comprimidas, "apenas querem explodir" (PUCHEU, 2014, p. 51).

Ao tensionar o limite das palavras, da forma e da linguagem poética ao máximo, parece estar em jogo em Claro Enigma a tentativa de, irritando-as ao máximo, fazê-las explodir e, nessa desintegração, forjar a sua resistência. Claro Enigma nos coloca em um impasse, desde o título, e é nesse impasse, que coloca em questão a própria poesia, que o poeta encontra, como diz Pucheu (2014), "a passagem para a poesia".

Dividido em seis partes, "Entre lobo e cão", "Notícias Amorosas", "O menino e os homens", "Selo de Minas", Os lábios cerrados" e "A Máquina do Mundo", o primeiro poema do livro já traz no título uma palavra que, de certa forma, resume aquele que será o tom principal de Claro Enigma: dissolução.

O título da primeira parte parece sugerir certo estado de coisas em que se está acuado, em risco, não vendo saída. Nesse sentido, o poema de abertura anuncia logo no início a chegada da noite, o escurecer, período de maior vigilância, quando o indivíduo se encontra mais exposto ao perigo. $\mathrm{O}$ eu do poema demonstra atitudes de aceitação e resignação, "braços cruzados", que conduzem à afirmação "esta rosa é definitiva,/ainda que pobre", ao mesmo tempo em que a palavra é colocada em "perene trânsito". Movimentos que parecem afirmar a poesia - rosa definitiva - mas pela via do negativo - ainda que pobre -, colocando a palavra no lugar de passagem, movimento, deslocamentos constantes. O poema seguinte, o soneto "Remissão", é marcado por profundo pessimismo, pelo desencanto de reconhecer que "nada resta, mesmo, do que escreves", constatando uma outra e inescapável dissolução: a do próprio tempo.

A madureza que aparece no poema "A ingaia ciência" se impõe no livro enquanto presença responsável por livrar a mão que escreve de encantos, e, no poema "O Legado", a fragilidade e certa autocrítica da poesia parece sugerida no verso "esses monstros atuais, não os cativa Orfeu,/a vagar, taciturno, entre o talvez e o se". Pessimista, o eu do poema diz: "Não deixarei de mim nenhum canto radioso, [...] De tudo quanto foi meu passo caprichoso/na vida, restará, pois o resto se esfuma,/uma pedra que havia em meio do caminho." (DRUMMOND, 1973, p. 236). Como legado, o poema deixa a pedra, pequena sobrevivente do seu desencanto, em meio a todo um resto que se esfuma.

Em uma dialética de restos e dissoluções, constantemente retomada nos poemas de Claro Enigma, em "Confissão" o eu do poema confessa apenas ter amado "aquele pássaro - vinha azul e doido - que se esfacelou na asa do avião". Tal pássaro azul e doido, desintegrado, talvez seja a imagem mesma de uma poesia já morta, porque aqui já recusada. Vítima da própria modernidade, ela se torna objeto de reflexão e cisma.

No poema "Um Boi Vê os Homens", o pessimismo do livro chega ao questionamento do homem e sua verdade, considerada, no poema, inútil. No verso que diz "Coitados, dir-se-ia não escutam/nem o canto do ar nem os segredos do feno,/como também parecem não enxergar o que é visível/", o poema parece fazer uso de sutil ironia. Na realidade, coitados seriam os homens, não os bois, já que nestes últimos há "pouca montanha" (pouca metafísica?), delicadeza e breve graça melancólica. Os homens, no poema, terminam quase ridículos diante do boi, a ruminar suas verdades que o boi facilmente despreza.

Em "Contemplação no Banco", o poema novamente tematiza a insuficiência da poesia, fala em "vão desenho", "roucas onomatopeias" e lamenta: "triste é não ter um verso maior que os literários,/é não compor um verso novo, desorbitado,/para envolver 
tua efígie lunar, ó quimera/que sobes do chão batido e da relva pobre." (DRUMMOND, 1973, p. 241).

No soneto "Oficina Irritada", o título expressa um estado que talvez possamos chamar de crise mesma da poesia - intensificação da questão poética - enquanto o conteúdo do poema traz a intenção do eu lírico de compor um soneto duro, escuro, "seco, abafado, difícil de ler". Nesse acúmulo de imagens negativas e mesmo violentas $^{56}$, o eu do poema busca aquilo que nenhum poeta ousou fazer, o poema difícil que, ao mesmo tempo, saiba ser não ser. Um poema ambíguo nesse sentido, instável, e por isso tão difícil de capturar - porque ele mesmo fugitivo, em dissolução, como tantas imagens até aqui acumuladas nos poemas anteriores - que no mesmo instante em que se pensa em toda sua dificuldade, provocadora também da sua efemeridade - "ninguém o lembrará" - divide espaço no universo com a estrela mais brilhante da constelação do Boieiro, esse claro enigma, imagem de racionalidade, lucidez.

Interessante notar nesse último terceto as imagens que coexistem e se tensionam, tem-se "cão mijando no caos", "tiro no muro", "Arcturo" e "claro enigma", deslocamentos que vão do mais baixo ao mais alto, atuando, de certa maneira, como indícios tensivos dessa oficina irritada que parece se debater na busca do poema hermético, difícil (tão difícil quanto a sua época), encenando na última estrofe a sua própria dificuldade e sugerindo, por fim, que este claro enigma que se deixa surpreender - talvez o próprio poema - é antes de tudo obscuro. O poema, dessa forma, se deixa surpreender como enigma - distante, fugitivo, ambíguo, capaz de, em sua dificuldade, atrair com a mesma violência com que expulsa o leitor ${ }^{57}$.

Ao pessimismo do poema "Tarde de Maio", que termina dizendo de "uma particular tristeza, a imprimir seu selo nas nuvens", e a uma retomada da temática do poema "A Flor e a Náusea", agora revisitada em outros termos no poema "Campo de Flores" - "[...] Era tempo de terra./Onde não há jardim, as flores nascem de um/secreto investimento em formas improváveis." (DRUMMOND, 1973, p. 251) -, o eu dos poemas de Claro Enigma segue confuso na luz que baixa, na treva que sempre se adensa, chegando a aprofundar a efemeridade e a morte de todas as coisas em uma espécie de aceitação resignada presente no poema "Morte das Casas de Ouro Preto".

Ao chegar à última parte do livro, composta de dois poemas, "A Máquina do Mundo" e "Relógio do Rosário", poemas intimamente ligados, tanto em sua construção formal quanto em sua temática, dois movimentos parecem destacar-se vindo como desdobramento de todo desencanto precedente, de todo questionamento e irritação do próprio fazer poético: o da recusa e o da revelação.

Construído em tercetos decassílabos, em diálogo pela forma e pela temática com

56 Como lembra Vagner Camilo, "em 'Oficina irritada' Drummond radicaliza sua atitude, movida agora por um desejo perverso de causar dor, traduzido em imagens aflitivas (como a do tendão de Vênus sob o pedicuro); no choque das imagens sublimes e grotescas; na musicalidade 'dura' (motivada pelo baque seco das consoantes plosivas) e no efeito sombrio dos versos (dada a incidência da sinistra vogal ' $u$ '); e sobretudo no hermetismo performático [...]" (CAMILO, 1999, p. 160).

57 O claro enigma ambíguo, fugidio, que traz para a poesia de Drummond essa dimensão das coisas que fogem, que não podem ser apreendidas totalmente, em contraposição àquilo que se deixa ver, que se revela, parece aproximá-lo de um aspecto comum a alguns poetas contemporâneos franceses influenciados por Francis Ponge. Trata-se da questão da mimesis crítica, ou mesmo negativa, ideia desenvolvida por Bénédicte Gorrillot em curso ministrado em 30 de setembro e 10 de outubro de 2015 na Universidade Estadual de Campinas. “Desde 1926, F. Ponge formula a ideia de uma mimesis crítica, para não dizer negativa, isto é, de uma figuração não mais da plena presença do mundo, [...] mas de uma figuração da fuga, da ausência de um real rebelde às formulações humanas". Como desenvolveu Bénédicte, os poetas buscam, por meio de mecanismos formais e explorações específicas da linguagem, exprimir nos poemas aquilo que ela chamou de "debandada do real" (GORRILLOT, 2015). 
Os Lusíadas, de Camões, no qual uma ninfa, considerada a mais bela, a ninfa Tétis, mostra a Vasco da Gama os segredos da máquina do mundo, fazendo com que o plano mítico - dos deuses - e o histórico - dos homens - encontrem-se; e também com a travessia de Dante na Divina Comédia, "A Máquina do Mundo" concentra imagens que dialogam com a obra de Drummond até o momento em que o poema é feito e sugerem possíveis modos de lê-lo e pensá-lo.

O caminhante da estrada de Minas, pedregosa, aparece logo no início, a palmilhar os caminhos vagamente em um final de tarde. O som dos seus sapatos é pausado e seco, há uma escuridão maior - céu de chumbo -, tem-se um ser desenganado a quem se abre, gratuita, a máquina do mundo, grandiosa e clara, não excessivamente, mas na medida exata que permitisse ao eu do poema contemplá-la, ainda que tendo suas pupilas gastas de tanto olhar o deserto, e a mente igualmente cansada de pensar. Já se tem aqui desenhada a imagem do eu lírico de tantos poemas de Drummond a confundirse com a do próprio poeta, o sujeito de olhares fatigados pela observação do homem e das coisas, de vocação reflexiva, sempre cismando.

No seu abrir-se majestoso, a máquina do mundo fala ao "sujeito noturno e miserável", atravessado por um resignado pessimismo, colado a uma íntima negatividade, mas não é possível ouvir sua voz, embora o poema reproduza seu discurso marcando-o com aspas. Ela o convida a ver, contemplar o que ele, por tanto tempo, inutilmente buscara. No breve, porém, muito claro discurso proferido pela máquina do mundo, algumas imagens se destacam, tais como a da procura, imediatamente seguida pelo retraimento daquilo que é procurado; o hermetismo, a dificuldade que caracterizam essa "total explicação da vida"; e, por fim, o movimento do revelar-se esquivo, construído no poema a partir do enjambement que, nesse caso particular, instala e reforça um abismo entre o adjetivo "esquivo" e a construção verbal reflexiva "se revelou". O abismo do enjambement parece reforçar uma situação em que ao esquivo (talvez o próprio real), que apenas foge, está dada a condição de jamais revelar-se. $\mathrm{O}$ enjambement termina por produzir, dessa forma, um outro sentido. Se o que lemos é "esquivo se revelou", o que a forma poética produz é "o esquivo apenas em abismo se revela". Nesse sentido, é como se a própria máquina do mundo dissesse da inglória busca do poeta, tematizasse a impossibilidade com a qual ele se bate e termina cansado, consumido, até incorporar nos versos a própria impossibilidade, tirando dela o poema.

Até aqui podemos identificar dois momentos em "A Máquina do Mundo". No primeiro, o caminhante é surpreendido, entre as trevas, pelo clarão inesperado da máquina do mundo. No segundo, a máquina fala por imagens que metaforizam a própria busca inútil do poeta. No terceiro momento, uma profusão de imagens descritivas se encena nos versos, o ritmo é pausado pelas frequentes vírgulas, mas, ao mesmo tempo, sobreposto e acumulado pelo emprego repetido da conjunção "e". Em poucos versos, passamos por uma apresentação de tudo, "tudo se apresentou nesse relance", como se fôssemos da origem ao fim do mundo, do inferno ao céu, percorrendo a espiral dantesca completa.

O caminhante oscila, quase cede aos apelos tão fáceis, no entanto, por um gesto de oposição que sinaliza o movimento inesperado do quarto e último momento do poema, cujo início é marcado e intensificado pela conjunção "mas", é introduzida justamente a recusa do eu lírico em colher a coisa ofertada. Toda a sua esperança em ver desvanecida a treva espessa que até então crescia perde força, ele baixa os olhos, a treva se adensa, pousa novamente sobre a estrada de Minas, pedregosa, e o caminhante segue vagaroso, com as mãos caídas.

Algumas imagens que descrevem o eu do poema na ocasião da sua recusa nos parecem importantes. Logo quando diz "como eu relutasse em responder", o uso do 
verbo "relutar", que traz em si a ideia de resistir a alguma coisa e, ao mesmo tempo, a de (re)lutar, lutar novamente, parece dizer algo sobre a atitude do poeta (associando aqui Drummond ao eu do poema) em opor resistências à esterilidade de sua época, ao assassinato da poesia, a todas as outras faltas e precariedades que ele transforma, por fim, em matéria de sua própria poesia. Um jogo de imagens opostas se desenha, tem-se:

fé, esperança, defuntas crenças versus neutra face._E, talvez, mais do que escolher entre uma coisa e outra, uma imagem mesma do poema indica uma oscilação tensiva entre elas, incorporando a ambiguidade, o fugitivo, a instabilidade do real, trazendo-a para dentro do próprio poema: "semelhante a essas flores reticentes/em si mesmas abertas e fechadas.” (DRUMMOND, 1973, p. 273). O enjambement mais uma vez reforça a caracterização das flores como reticentes. A suspensão do sentido prolonga a ideia de indeterminação e deixa mais acentuada a hesitação, a oscilação das flores, que parece ser a oscilação da própria poesia $($ flor $=$ poesia $)$ e do próprio poeta - semelhança que fica sugerida no adjetivo "semelhante", colocado no início do verso.

As imagens finais trazem um eu lírico cansado, sem curiosidade, que baixa os olhos. Os três últimos tercetos impressionam por serem tão simples diante de imagens precedentes tão grandiosas. Há, ao que parece, um esforço de simplicidade nos últimos versos. A máquina do mundo se recompõe, logo após ser repelida, "miudamente", o que é um advérbio interessante, pois indica minúcia mas, ao mesmo tempo, faz lembrar daquilo que é miúdo, pequeno.

O passo vagaroso do último verso impõe um ritmo que agora é lento, sem grandes acidentes, a não ser o pequeno tropeçar em alguma pedra, não descartado pelo poema, apenas posto em suspenso (a estrada de Minas é pedregosa). Por fim, a imagem que encerra o poema, "de mãos pensas", aponta uma direção, a da terra, as mãos pensas se voltam para baixo, estão descaídas, pendidas, tombadas, e são também as mãos que pensam, que escrevem.

$\mathrm{Na}$ recusa fundamental desse poema parece existir a escolha de um lugar precisamente o lugar do meio do caminho -, o lugar intervalar das oscilações, das reflexões, das cismas, dos questionamentos, justamente por não ser o lugar de lá - do outro lado do caminho -, lugar que o eu do poema ocuparia se tivesse aceitado a máquina do mundo - e também por não ser o início do caminho -, lado de cá, conhecido, seguro, que não promete riscos, tampouco indecisões, lugar que $o$ caminhante teria ocupado se não se sentisse, ainda que por breve instante, seduzido pelo conhecimento gratuito da "ordem geométrica de tudo". O meio do caminho é o lugar instável, do claro enigma, que ainda pode ser ao mesmo tempo enigma e claro, e assim obscuro, ambíguo na sua instabilidade fundamental. Só no meio do caminho poderia o poeta dar conta do real, igualmente instável, ambíguo, fugitivo. Por isso, as "mãos pensas", se são caídas, abandonadas, são mãos também pensantes, que cismam embaladas pelo caminhar vagaroso desse eu que se faz ainda mais grandioso que a máquina do mundo ao recusá-la, na dialética de fazer-se grandioso ao escolher justamente o lugar das coisas pequenas e não das verdades universais, o lugar do poeta portador da lanterna de bolso, e não o do poeta portador do fogo sagrado.

"A Máquina do Mundo" desenha o espaço do entrelugar na obra poética de Drummond (embora este já viesse sendo rascunhado desde o início), superando as fronteiras e criando o espaço de uma dialética tensiva do pequeno e do grandioso, onde o pequeno se monumentaliza, ganha dimensão poética, e o monumento se torna pequeno. Tal dialética torna as coisas mais complexas, já que não parece haver necessariamente uma opção pelo poético ou pelo não poético, mas a constelação de um no outro. No lugar de escolhas, a cisma, no lugar de certezas, o estado suspenso da dúvida. Trata-se do mesmo movimento, aqui mais acentuado, também percebido por 
Alberto Pucheu (2014) no poema "Nosso tempo", de A Rosa do Povo.

[...] superar as fronteiras entre o suposto lírico e o suposto antilírico, entre o suposto poético e o suposto não poético, entre o suposto canto e o suposto não canto, entre o verso e a prosa, entre o impossível de se contar e o narrativo, entre o indescritível e o descritível, mesclando-os. [...] a poesia e a antipoesia [...] se encontram em Drummond (PUCHEU, 2014, p. 53).

A tentativa de leitura do poema "A Máquina do Mundo" parece se complementar quando olhamos para o poema que vem logo na sequência, "Relógio do Rosário". Enquanto "A Máquina do Mundo" começa nas trevas e termina nelas, mesmo momentaneamente interrompidas pelo clarão da aparição, "Relógio do Rosário" começa com uma treva do som que vai baixando, atravessando o dia claro, e termina com o mesmo som expulsando a treva. Poderíamos assim pensar na organização do primeiro poema como sendo treva - clarão - treva, e do segundo, luz - treva - luz. Construído em dísticos, o poema também introduz seu movimento essencial a partir da mesma conjunção "mas", assim como em "A Máquina do Mundo", indicando uma reviravolta que aqui é de outra ordem.

Logo nos primeiros versos, percebemos que, ao eu do poema, ao contrário do que se passa em "A Máquina do Mundo", é dada a oportunidade da decifração, da descoberta, que não acontece no poema anterior devido à recusa do caminhante. $\mathrm{O}$ movimento de ir "ao âmago de tudo" está dado nos dois primeiros dísticos de "Relógio do Rosário":

\author{
Era tão claro o dia, mas a treva \\ do som baixando, em seu baixar me leva \\ pelo âmago de tudo, e no mais fundo \\ decifro o choro pânico do mundo,
}

(DRUMMOND, 1973, p. 273)

Aqui, já aparece a decifração dos segredos do mundo, da própria existência, que em seguida é descrita no poema de forma extremamente pessimista, marcada por inescapável "dor primeira e geral, esparramada". Nem mesmo o amor é poupado quando o eu do poema nega a sua capacidade de explicar-se e nos explicar, e viver, enfim, se resume a um constante estar doendo. Neste ponto do poema é que a conjunção "mas" marca novamente a reviravolta. Se, em "A Máquina do Mundo", ao escrever "mas" o poema preparava a sua recusa, aqui, o mesmo "mas" prepara a revelação que acompanha a morte.

"Relógio do Rosário" se passa em um cemitério, lugar de morte, assim como a própria imagem da máquina do mundo também não deixa de ser uma imagem de morte. Nesse sentido, "Relógio do Rosário" parece completar "A Máquina do Mundo", pois, enquanto no primeiro poema a experiência que se tem parece ser uma experiência de quase morte, em "Relógio do Rosário" a morte já se deu quando se escuta o som do relógio, sinal também da passagem do tempo (o tempo que nos mata). "O columbário/já cinza se concentra, pó de tumbas,", em outras palavras, à medida que há cinza no columbário, a morte já se deu. No entanto, em dois movimentos novamente tensivos e dialéticos, o columbário a um só tempo é morte e vida: já cinza se concentra e já se permite azul, "risco de pombas". "Relógio do Rosário" parece ser uma espécie de poema/morte, enquanto "A Máquina do Mundo" seria o poema/vida (sendo essa vida também uma espécie de quase morte). A própria organização temporal que fizemos há pouco dos dois poemas parece indicar essa associação. Treva-clarão-treva sintetizaria 
um movimento da vida na visão do eu dos poemas de Claro Engima, marcada constantemente pela treva, pela escuridão, pelo perigo, pelas dificuldades da existência, que, podem, no entanto, ser interrompidas, vez ou outra, por clarões, um deles sendo talvez a própria poesia. Já o movimento da morte é aquele da luz - treva - luz; a morte é sempre vista como esse clarão que inicialmente enxergamos, mas ao qual chegamos apenas depois de passar pelo caminho escuro.

Talvez aqui, ao final do livro, soe também no relógio do rosário o instante em que se morre, em que se chega ao final, quando só então será de fato claro o enigma. Ao caminhante da estrada pedregosa de Minas, entretanto, lhe interessa a vida, ainda que pobre, o claro enigma, ainda que obscuro, lhe interessa a poesia, ainda que recusada.

\section{Drummond e a lição das coisas}

Após a experiência de intensificação da questão (anti)poética e da própria existência que parece se realizar em Claro Enigma, é interessante perceber como as discussões deste livro de 1951 contribuíram e prepararam, de certa forma, a poesia mais objetiva, atenta às coisas e às palavras, presente no livro Lição de Coisas, que reúne poemas escritos entre 1959 e 1962.

Haroldo de Campos no artigo "O poema como objeto de palavras", publicado no jornal O Estado de S. Paulo em $1962^{58}$, lembrando o próprio Ponge e o seu livro Le Parti pris de choses, também destaca a importância dada no livro de Drummond às palavras. Estas últimas apareceriam em Lição de Coisas, segundo Haroldo, como a resolução última de todos os elementos que, de uma forma ou de outra, sempre se fizeram importantes no trabalho poético de Drummond, entre eles, a emoção, a paisagem, o ser e a revolta.

\footnotetext{
Nesta Lição de Coisas, se não há o Parti pris des choses de Ponge [...], se não há a atitude lucreciana que preside o roteiro do poeta francês, há porém (e nisto se parecem) a consideração do poema como objeto de palavras, a resolução última de tudo - emoção, paisagem, ser, revolta - na suprema instância da coisa-palavra. Aqui, o poema se abre a todas as pesquisas que constituem o inventário da nova poesia; ei-lo incorporando o visual, fragmentando a sintaxe, montando ou desarticulando vocábulos, praticando a linguagem reduzida. Não que estas perquirições surgissem só hoje em Drummond, [...] Mas sim que, em Lição de Coisas, elas se intensificam e se radicalizam (CAMPOS, 1973, p. 37- 38).
}

Ao pensarmos, por exemplo, no poema "Palavra", presente em Lição de Coisas, essa importância dada à palavra, essa manipulação da forma poética, certa liberdade inventiva, são rapidamente percebidas em um poema que aproxima, tensionando verso após verso, palavras de sentidos completamente opostos, mas que juntas, aproximadas pelo som e pela forma, produzem novos sentidos, novos focos de propagação poética. Ao dizer "Isso é Aquilo", o que se ensaia no poema é uma fascinante coexistência de contrários, que não deixa de ser tensiva, expondo os gestos de uma poética na qual "os paradoxos, ao invés de evitados, são cultivados, as contradições, ao invés de ocultadas, expostas.” (PUCHEU, 2014, p. 54). Nela surge, como um vestígio de Mallarmé ${ }^{59}$, a

58 O artigo de Haroldo de Campos foi reimpresso na edição da obra reunida de Drummond de 1973, utilizada neste trabalho.

59 A palavra "ptyx" surgiu no poema de Mallarmé "Ses purs ongles très haut dédiant leur onyx", conhecido também como "Soneto em ix". Em texto de Fabiana Angélica Nascimento, "Ptyx: a palavra em ação", são discutidos os possíveis sentidos para a palavra e também a sua relação com a obra de Mallarmé. Em um dos momentos do texto, ela traz aquele que seria um possível significado da palavra: 
figura do ptyx, espécie de palavra incógnita, cujo sentido se esquiva (assim como a forma se esquiva nesse poema de Drummond), um outro claro enigma obscuro, ou ainda, talvez, uma outra forma da pedra, a mesma e sempre outra - precária e poética (porque supostamente não poética) - pedra no meio do caminho.

\section{REFERENCIAS}

ANDRADE, Carlos Drummond de. Poesia completa e prosa organizada pelo autor. Nota editoral: Afrânio Coutinho. Introd. Emanuel de Moraes. Rio de Janeiro: Companhia José Aguilar Editora, 1973.

Poesia Nobre. In: . Passeios na Ilha - Poesia completa e prosa. Rio de Janeiro: Companhia José Aguilar Editora, 1973.

BAUDELAIRE, Charles. O Spleen de Paris (Pequenos Poemas em Prosa). Trad. António Pinheiro Guimarães. Lisboa: Relógio D’Água, 1991.

CAMILO, Vagner. Da rosa do povo à rosa das trevas: classicismo, melancolia e cosmovisão trágica na lírica de Drummond (1948-1951). 1999. Tese (doutorado) Instituto de Estudos da Linguagem, Universidade Estadual de Campinas, Campinas, 1999.

CAMPOS, Haroldo de. O poema como objeto de palavras. In: ANDRADE, Carlos Drummond de. Poesia completa e prosa organizada pelo autor. Nota editoral: Afrânio Coutinho. Introd. Emanuel de Moraes. Rio de Janeiro: Companhia José Aguilar Editora, 1973.

GORRILLOT, Bénédicte. Esquisse d'une géographie poétique française contemporaine: l'heritage varié de F. Ponge. Curso ministrado em 30 de setembro e $1^{\circ}$ de outubro de 2015 na Universidade Estadual de Campinas.

NASCIMENTO, Fabiana Angélica. Ptyx: a palavra em ação. Lettres Françaises, Araraquara, v. 2, n. 14 , p. 275-284, 2013. Disponível em: $<$ http://seer.fclar.unesp.br/lettres/article/viewFile/5920/5170>. Acesso em: 29 out. 2015.

PONGE, Francis. My creative method. In: . Le Grand recueil, II. Méthodes. Paris: Éditions Gallimard, 1961.

Le savon. In: Collection L'Imaginaire ( $\left.{ }^{\circ} 279\right)$. Paris: Gallimard, 1992.

PUCHEU, Alberto. Carlos Drummond de Andrade: um ex-poeta, um poeta perturbado, um poeta precário. In: SCRAMIM, Susana; DI LEONE, Luciana. (orgs.) Ler Drummond hoje. São Paulo: Rafael Copetti Editor, 2014.

VALÉRY, Paul. Poesia e Pensamento Abstrato. In: Variedades. Trad. Maiza Martins de Siqueira. São Paulo: Iluminuras, 1991.

“De acordo com Octavio Paz (1972) e Gretchen Kromer (1971), atribui-se a Émile Noulet a elucidação do mistério: '[...] se nos remontarmos à origem grega da palavra, ficamos conscientes de que a ideia de dobra é fundamental... ptyx significa uma concha, um desses caracóis que ao aproximarmos do ouvido nos dão a sensação de escutar o rumor do mar'." 